\title{
Estimation of vertical profiles of leaf drying times after daytime rainfall within a Bornean tropical rainforest
}

\author{
Tomonori Kume, ${ }^{1 *}$ Odair J Manfroi, ${ }^{2}$ Masakazu Suzuki, ${ }^{2}$ Katsunori Tanaka, ${ }^{3}$ Koichiro Kuraji, ${ }^{4}$ \\ Michiko Nakagawa, ${ }^{5}$ Hikaru Komatsu ${ }^{1}$ and Tomo'omi Kumagai ${ }^{6}$ \\ ${ }^{1}$ Kasuya Research Forest, Kyushu University, Sasaguri, Fukuoka 811-2415, Japan \\ ${ }^{2}$ Graduate School of Agricultural and Life Sciences, The University of Tokyo, Bunkyo-ku, Tokyo 113-8657, Japan \\ ${ }^{3}$ Frontier Research Center for Global Change, Japan Agency for Marine-Earth Science and Technology, 3173-25 Showamachi, Kanazawa-ku, \\ Yokohama, Kanagawa 236-0001, Japan \\ ${ }^{4}$ University Forest in Aichi, The University of Tokyo, Seto, Aichi 489-0031, Japan \\ ${ }^{5}$ Graduate School of Bioagricultural Sciences, Nagoya University, Chikusa-ku, Nagoya 464-8601, Japan \\ ${ }^{6}$ Shiiba Research Forest, Kyushu University, Shiiba-son, Miyazaki 883-0402, Japan
}

\begin{abstract}
:
South-east Asian Bornean tropical rainforests have large and complex canopy structures. To clarify how forest structure affects wet-canopy evaporation, it is necessary to consider wet-canopy evaporation processes within the forest canopy, such as vertical profiles of canopy drying time. In a previous study a method was proposed that utilizes sap flow measurements to estimate canopy drying time after rainfall (CDTobs) during daytime. In this present study, the method was applied to estimations of the vertical variations in CDTobs in 11 individual trees of various heights, ranging from $2.7 \mathrm{~m}$ to $53 \mathrm{~m}$. The study derived vertical profiles and showed that the lengths of CDTobs in lower canopy trees were $2-4 \mathrm{~h}$ longer than those in the upper canopy trees. The new method for CDTobs profiles presented in this study, which is available for validation of multi-layer biosphereatmospheric models, is a useful illustration for clarifying wet-canopy evaporation processes in tropical rainforests. Copyright (c) 2008 John Wiley \& Sons, Ltd.
\end{abstract}

KEY WORDS sap flow; wet canopy evaporation; canopy drying time; multi-layer model

Received 9 March 2007; Accepted 20 November 2007

\section{INTRODUCTION}

Tropical rainforests are a major latent energy source, having an influence on global and regional water cycling (Lean and Warrilow, 1989; Kanae et al., 2001; Mabuchi et al., 2005). In tropical forests in south-east Asia, where the relative deforestation rates are among the world's highest (Houghton and Hackler, 1999; Malhi and Grace, 2000), predicting the consequences of landuse changes for evapotranspiration is a critical issue. Evapotranspiration has two quite different aspects that depend on whether the canopy is wet or dry; wet- and dry-canopy evaporation. In terms of water cycling in tropical forest ecosystems, because of the large amount of rainfall involved, wet-canopy evaporation is a hydrologic component of major importance in determining the water budget of forest areas (Jackson, 1975; Lloyd et al., 1988; Scatena, 1990; Jetten, 1996; Dykes, 1997; Asdak et al., 1998; Schellekens et al., 2000; Kuraji and Tanaka, 2003; Manfroi et al., 2006). Therefore, measurements and models of wet-canopy evaporation are needed to clarify the effects on water cycling in this region for land use.

\footnotetext{
* Correspondence to: Tomonori Kume, Kasuya Research Forest, Kyushu University, Sasaguri, Fukuoka 811-2415, Japan.

E-mail: kumett@forest.kyushu-u.ac.jp
}

Tropical rainforests in south-east Asia are characterized by a complex canopy structure because of the diversity of tree species and tall emergent trees, some of which are taller than $70 \mathrm{~m}$ (Kira, 1978; Whitmore, 1994). This results in strong vertical gradients of micro-meteorological factors such as solar radiation, humidity, and wind speed within a forest canopy (Kumagai et al., 2001). Such vertical gradients can affect the total amount of wet-canopy evaporation, or the duration of wet-canopy evaporation (Watanabe and Mizutani, 1996). One-dimensional multi-layer biosphere-atmospheric models (multi-layer models) are promising tools for understanding how forest structure impacts on wet-canopy evaporation. By using multilayer models, vertical variations in wet-canopy evaporation have been reproduced in some studies conducted in temperate forests (Watanabe and Mizutani, 1996; Takanashi et al., 2003; Tanaka K, 2002; Park and Hattori, 2004). However, to the authors' knowledge, there are no studies examining wet-canopy evaporation processes within a forest canopy in a tropical rainforest using multi-layer models. In addition, many multi-layer models have been developed to reproduce biosphere-atmospheric $\mathrm{CO}_{2}$ and $\mathrm{H}_{2} \mathrm{O}$ exchange under dry-canopy conditions (Williams et al., 1998; Lai et al., 2000; Baldocchi and Wilson, 2001; Kumagai et al., 2006). 
To reproduce wet-canopy evaporation using multilayer models, a prerequisite is measurements of wetcanopy evaporation processes. In previous studies, latent heat fluxes measured by an eddy covariance method (Watanabe and Mizutani, 1996; Williams et al., 1998; Baldocchi and Wilson, 2001; Tanaka et al., 2003; Takanashi et al. 2003), and net rainfall measurements based on event measurements of throughfall and stemflow (Tanaka et al., 2003) have been used to validate multi-layer models. In a recent study, vertical profiles of canopy drying time (or wet canopy duration) after rainfall within a forest canopy, which is the period required to dry out a canopy exposed to rainfall, were successfully used as validation data for a multi-layer model (Takanashi et al., 2003). Neglecting canopy drying time after rainfall within a forest canopy as part of the validation data could cause serious errors in reproducing wetand dry-canopy evaporation, especially in tropical rainforests where short rain events occur frequently (Lloyd et al., 1988; Noguchi et al., 2003; Manfroi et al., 2006). However, the vertical variations in canopy drying time after rainfall within a forest canopy have never been shown in tropical rainforests, because of the large and complex canopy structure, and the lack of a facility to carry out measurements (Kume et al., 2006).

This study was undertaken to illustrate measurements of vertical variations in canopy drying time, and to clarify the characteristics of vertical variations in canopy drying time after rainfall within a tropical rainforest canopy. To achieve this, vertical variations in canopy drying time after rainfall within a forest canopy were estimated from sap flow measurements conducted in individual trees of various heights, ranging from $2.7 \mathrm{~m}$ to $53 \mathrm{~m}$, in a Bornean tropical rainforest. Canopy drying time after rainfall has usually been detected by wetness sensors (Lindroth, 1993; Tanakanashi et al., 2003). However, this study used sap flow measurements as a detector of canopy wetness, because sap flows, which decrease during canopy wetting, can provide information about integrated leaf wetness conditions throughout the entire canopy of a tree (Bosveld and Bouten, 2003; Takanashi et al., 2003; Kajitani et al., 2005; Kume et al., 2006). In addition, since a sensor for sap flow measurements can be installed at an accessible point, the method used has advantages over the use of wetness sensors that require special platforms for measurements.

\section{MATERIALS AND METHODS}

\section{Site}

This study was carried out in a lowland mixeddipterocarp forest in the Lambir Hills National Park, Sarawak, Malaysia $\left(4^{\circ} 20^{\prime} \mathrm{N}, 113^{\circ} 50^{\prime} \mathrm{E}\right)$, situated approximately $30 \mathrm{~km}$ southwest of Miri, Sarawak. The mean annual temperature at Miri airport, $20 \mathrm{~km}$ from the study site, is approximately $27^{\circ} \mathrm{C}$, with small seasonal fluctuations, and the mean annual rainfall for the period
1968-2001 was approximately $2700 \mathrm{~mm}$ with some seasonal variation (Kumagai et al., 2005; Gomyo and Kuraji, 2006). Rainfall measurements, which commenced in January 1999 in this park, show that rainfall is composed of relatively more intense storms that occur between 1 and $4 \mathrm{pm}$, and less intense but longer duration storms occurring between 9 pm and 6 am (Kume et al., 2006; Manfroi et al., 2006). Most rain events in this park can be divided into two types; afternoon rainfall around an afternoon peak, and midnight rainfall around a midnight peak

In this park, a $93 \mathrm{~m}$ tall crane facility and a $49.5 \mathrm{~m}$ tree tower have been constructed for long-term ecohydrological studies (Nakashizuka et al., 2001; Ozanne et al., 2003). Measurements in this study were mainly conducted in the area surrounding the crane, a 4 ha study plot divided into 400 subplots ( $10 \mathrm{~m} \times 10 \mathrm{~m}$ square grid). Sap flow measurements and an inventory of all trees with a diameter at breast height $>1 \mathrm{~cm}$ reported here were carried out in one of the subplots. To include sufficient samples of emergent trees, some sap flow measurements were carried out around the tree tower, which is located approximately $540 \mathrm{~m}$ south-west of the crane.

\section{Forest structure}

The Park has an area of 6949 ha, $85 \%$ of which is covered by the lowland mixed-dipterocarp forest that is common in Borneo (Yamakura et al., 1995; Itoh et al., 1997; Condit et al., 2000). It has a continuous canopy height of approximately $50 \mathrm{~m}$. All trees with a diameter at breast height $(\mathrm{DBH})>1 \mathrm{~cm}$ in a subplot were measured for DBH, tree height, the height to the first living branch, and the species was identified. The mean density of trees with DBH $>1 \mathrm{~cm}$ was 6500 trees ha ${ }^{-1}$, of which about $90 \%$ had DBH $<10 \mathrm{~cm}$, and the mean density of trees with DBH $>10 \mathrm{~cm}$ was 700 trees ha ${ }^{-1}$. Mean total basal area was $43.3 \mathrm{~m}^{2} \mathrm{ha}^{-1}$. A more complete description of the lowland tropical rainforest is available in Nakagawa et al. (2000) and Manfroi et al. (2004).

The leaf area index (LAI) was measured using a pair of plant canopy analysers (LAI-2000, Li-Cor, Lincoln, Nebraska, USA) every $5 \mathrm{~m}$ on a $30 \times 30 \mathrm{~m}^{2}$ subplot. The LAI ranged spatially from 4.8 to $6.8 \mathrm{~m}^{2} \mathrm{~m}^{-2}$ with a mean of $6.2 \mathrm{~m}^{2} \mathrm{~m}^{-2}$ (Kumagai et al., 2004). Vertical variations in LAI were also measured at $5 \mathrm{~m}$ intervals along four vertical observation lines using the crane facility and the pair of plant canopy analysers (Kumagai et al. 2006). The accumulated LAI data measured from the top of the canopy to the forest floor showed that leaves were distributed evenly within the canopy (Figure 1). In this study, all trees in a subplot were categorized into four levels according to Kira (1978). The four categories of tropical forest canopy were designated depending on the canopy position as follows; a first layer of emergent trees, a second layer of the crowns of large trees, a third layer of the crowns of small trees, and a fourth layer of shrub (Figure 1). This study assumed that the canopy position could be a primary factor influencing the leaf drying time of each tree because of the strong vertical gradients of 
meteorological conditions within the forest canopy at this site (Kumagai et al., 2001). Two to four trees in each canopy level were selected for sap flow measurements regardless of tree species (Table I).

\section{Sap flow measurements}

This study used the diurnal variation in sap flow velocities in individual trees as a detector of canopy wetness. Sap flow measurements were conducted using the thermal heat-pulse method (Closs, 1958; Marshall, 1958) in 11 sample trees (Table I) from August 2004 through October 2004. A heat pulse sensor (HP-1, Hayasi Denko, Tokyo, Japan) containing a heater probe and two thermistor probes $(2.0 \mathrm{~mm}$ in diameter, $50 \mathrm{~mm}$ in length) was used. The heater probe was inserted radially into the stem at a height above the buttress in emergent trees in canopy level 1 and at about $1 \mathrm{~m}$ height above the ground in individuals in canopy levels 2, 3, and 4 (Table I). The two thermistor probes were vertically aligned asymmetrically around the heater probe. The upper and lower probes were spaced 10 and $7 \mathrm{~mm}$, respectively, from the heater probe. The sensors were

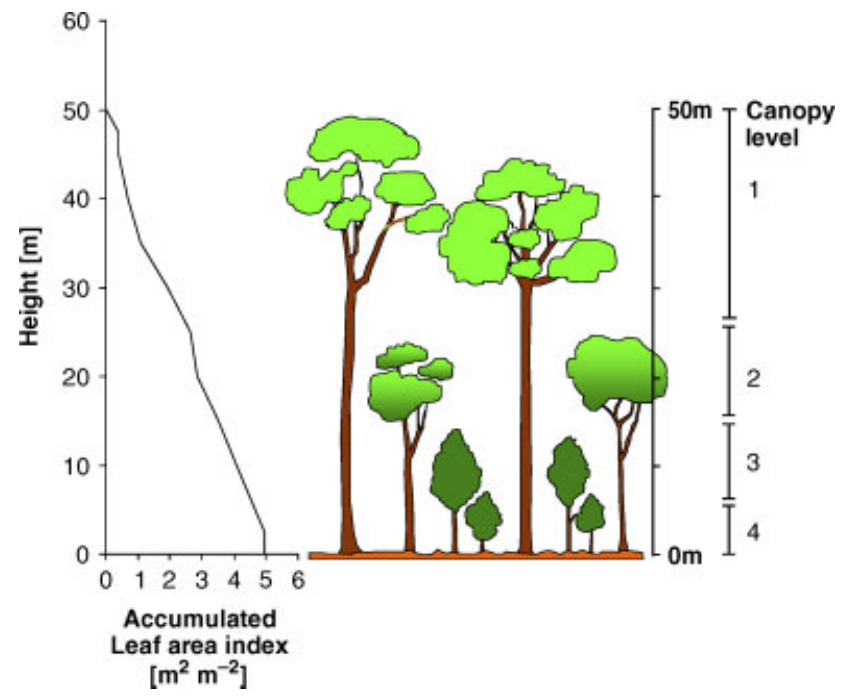

Figure 1. (a) Vertical distribution of the leaf area index determined by one vertical observation line; after Kumagai et al. (2006). (b) Schematic representation of the sample trees; categorized into four levels depending on canopy position installed in holes drilled with a gauge guide into the outer xylem to a depth at which the sap flow velocity peaked in the radial profiles. A heat-pulse tracer was released for $1.5 \mathrm{~s}$ every $20 \mathrm{~min}$, and the heat pulse velocity was stored in a data logger (CR10X, Campbell Scientific, Logan, UT, USA). To account for the influence of sap flow interruption around an implanted sensor, the heat pulse velocity was adjusted to the sap flow velocity using Swanson's method (Swanson and Whitfield, 1981; Kominami and Suzuki, 1993).

Time lags between canopy transpiration and basal sap flow more than the measurement interval (i.e. $20 \mathrm{~min}$ ) were insignificant when sap flow velocities in a branch at $50 \mathrm{~m}$ height and a stem above the buttresses were measured in Dryobalanops aromatica. Cross- correlation analysis showed strong correlation between branch and stem sap flow velocities in D. aromatica $(r=0.98$ at zero time lag) (Kume et al., 2007a), and also among the stem sap flow velocities measured in the $50 \mathrm{~m}$ tall emergent trees (mean $r=0.96$ at zero time lag). Furthermore, it has been reported that time lags between canopy transpiration and stem sap flows decreased with decreases in tree size in a neo-tropical forest (Goldstein et al., 1998). These results mean that the time lag between canopy transpiration and sap flow in a stem owing to internal water storage and hydraulic resistance (Landsberg et al., 1976; Phillips et al, 1997; Kumagai, 2001) was negligible at this site and that almost the same diurnal variations in sap flow velocities would be obtained regardless of differences in the sensor positions for the sample trees. However, some studies have reported remarkable time lags in a tropical evergreen forest (Phillips et al., 1999; Goldstein et al., 1998).

\section{Meteorological measurements}

Solar radiation was sampled every $5 \mathrm{~s}$ using a solar radiometer (MS401, EKO, Tokyo, Japan), and an averaging period of $10 \mathrm{~min}$ was used (CR10X data logger, Campbell Scientific, Logan, UT, USA). Rainfall was measured using a tipping bucket rain gauge $(20 \mathrm{~cm}$ in diameter and $0.5 \mathrm{~mm}$ in tip resolution; RS102, Ogasawara Keiki, Tokyo, Japan) and its tip timing was

Table I. Characteristics of sample trees selected for sap flow measurements

\begin{tabular}{|c|c|c|c|c|}
\hline Family & Species & Height $[\mathrm{m}]$ & Stem diameter $[\mathrm{cm}]$ & Lowest crown's height [m] \\
\hline Dipterocarpaceae & Dryobalanops aromatica & $53 \cdot 4$ & $142 \cdot 7$ & $34 \cdot 9$ \\
\hline Dipterocarpaceae & Shorea beccariana & $51 \cdot 3$ & $97 \cdot 5$ & $38 \cdot 6$ \\
\hline Dipterocarpaceae & Dipterocarpus pachyphyllus* & $49 \cdot 2$ & $113 \cdot 1$ & $31 \cdot 2$ \\
\hline Moraceae & Ficus crassiramea* & $45 \cdot 7$ & $17 \cdot 8$ & $31 \cdot 2$ \\
\hline Loganiaceae & Fagraea caudata & $42 \cdot 5$ & $131 \cdot 1$ & $20 \cdot 9$ \\
\hline Dipterocarpaceae & Shorea laxa & $18 \cdot 5$ & $13 \cdot 8$ & $5 \cdot 2$ \\
\hline Dipterocarpaceae & Shorea acuta & $18 \cdot 5$ & $19 \cdot 1$ & $7 \cdot 0$ \\
\hline Euphorbiaceae & Beccaurea sarawakensis & $12 \cdot 0$ & $10 \cdot 1$ & $7 \cdot 8$ \\
\hline Oxalidaceae & Sarcotheca xanthophyllum & $10 \cdot 0$ & $7 \cdot 0$ & $4 \cdot 8$ \\
\hline Ebenaceae & Diospyros pendula & $5 \cdot 2$ & $3 \cdot 6$ & $1 \cdot 6$ \\
\hline Burseraceae & Dacryodes rostrata & 2.7 & $1 \cdot 4$ & $0 \cdot 5$ \\
\hline
\end{tabular}

\footnotetext{
* Sample tree located at the crane site about $540 \mathrm{~m}$ south-west of the subplot.
} 
recorded with a data logger (HOBO event, Onset Computer, Bourne, MA). These measurements were conducted at $85.8 \mathrm{~m}$ on the crane. Air temperature and humidity, measured using a thermohygrograph (HMP45, Vaisala, Helsinki, Finland), were recorded at $10 \mathrm{~min}$ intervals with a data logger (SQ1250, Cambridge, UK) at $76.3 \mathrm{~m}$ on the crane. At the same height, wind speed was sampled every $5 \mathrm{~s}$ using a three-cup anemometer (AC750, Makino, Tokyo, Japan), and an averaging period of 10 min was used (CR10X).

\section{Definition of canopy drying time}

Transpiration from whole or partially wet leaves is lower than that from completely dry leaves because atmospheric evaporative energy is consumed by wetcanopy evaporation in addition to transpiration (Rutter et al., 1975; Watanabe and Mizutani, 1996; Bosveld and Bouten, 2003). The decrease in transpiration due to canopy wetting can be monitored continuously by sap flow measurements (Bosveld and Bouten, 2003; Takanashi et al., 2003; Kajitani et al., 2005). In a previous study, canopy drying time after rainfall was defined from sap flow velocities (Kume et al., 2006).

At this site, when sap flow velocity after rainfall becomes equal to the value of the sap flow velocity assumed for bright days, it can be assumed that the effect of leaf wetness on transpiration is removed and that the canopy is completely dry. Sap flow velocity measured at the same time on bright days can have almost the same value throughout the year at this aseasonal site; thus, sap flow velocity that is lower than expected after rainfall on a bright day is thought to be due to the canopy wetness at this site, where cloudy weather after rainfall tends to abruptly change to sunny (Kume et al., 2006).

Figure 2 shows the diurnal variations in the sap flow velocity averaged over 10 bright days with standard deviation, and the sap flow velocity for a rainy day as well as during the actual rainfall. In a previous study, estimated canopy drying time by sap flow velocities (CDTobs) was defined as follows (a more complete background and practical limitation of the CDTobs is available in Kume et al. (2006)):

$$
\mathrm{CDT}_{S} \leqq \mathrm{CDT}_{0} \text { ss } \leqq \mathrm{CDT}_{L},
$$

where $\mathrm{CDT}_{S}$ is defined as the period from the time rain ceased $(A)$ to a specific time $S, \mathrm{CDT}_{L}$ is defined as the period from $A$ to a specific time $L, S$ is the time when sap flow velocity after rainfall exceeds the average minus the standard deviation of the sap flow velocity averaged over 10 bright days, and $L$ is the time when the sap flow velocity after rainfall exceeds the average of the sap flow velocity averaged over 10 bright days. This study assumes that the wet canopy dries out in the period from $S$ to $L$, and that CDTobs is defined as ranging between $\mathrm{CDT}_{S}$ and $\mathrm{CDT}_{L}$ at each rain event. The bright days selected in this study were the top 10 days showing larger daily solar radiations in the measurement period without rain. The diurnal variations in the sap

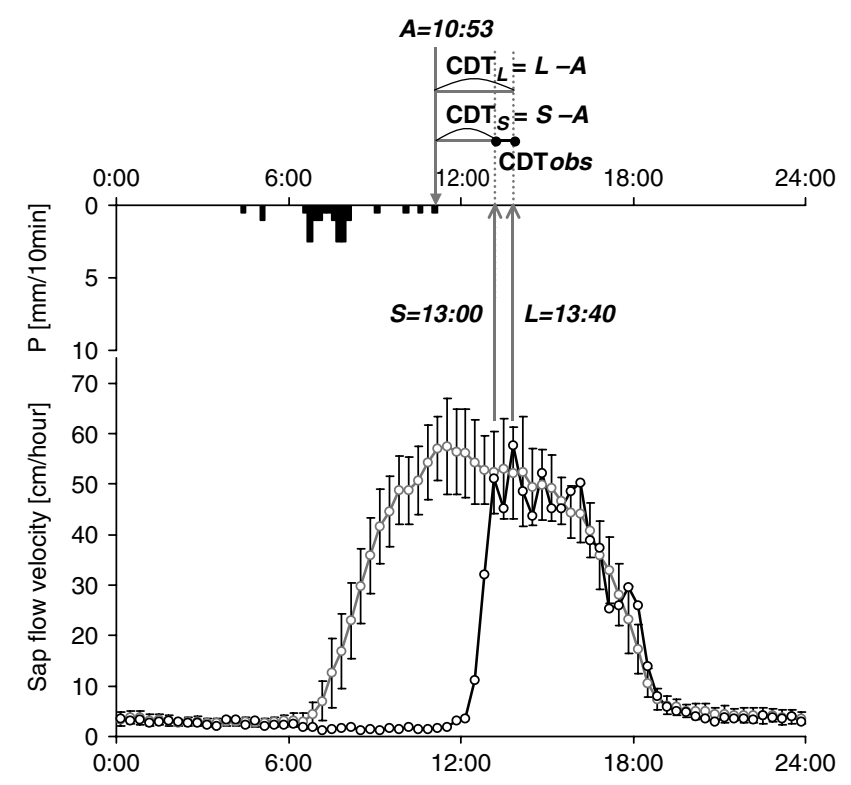

Figure 2. Definition of estimated canopy drying time after rainfall (CDTobs) after Kume et al. (2006). (a) Rainfall (P); (b) diurnal courses of sap flow velocity during a rainy (black line) period and the average over 10 bright days (gray line). Vertical bars indicate standard deviation. $\mathrm{CDT}_{S}$ and $\mathrm{CDT}_{L}, A, S, L$ are detailed in the text

flow velocity averaged over these 10 bright days were calculated for each tree. Although the '10 days' was itself an arbitrary number, it was confirmed that the average and the standard deviation of the sap flow velocities averaged over more than 10 days were almost same as the values averaged over 10 days. Consequently, in the case of the rain event in Figure 2, $\mathrm{CDT}_{S}$ and $\mathrm{CDT}_{L}$ are defined as $127 \mathrm{~min}$ and $167 \mathrm{~min}$, respectively, while CDTobs is defined as the range between 127 and $167 \mathrm{~min}$.

In this study, three criteria were used to select target rain events to derive CDTobs: (1) Rainfall ceased in the daytime from 06:00 to 17:00. (2) The period of no rainfall between each rain event exceeded $2 h$. (3) Total rainfall for each rain event exceeded a threshold of $1.5 \mathrm{~mm}$. There are two reasons for the three criteria; sap flow occurs during the daytime, and the studied canopy needs to be fully wet at the time rainfall ceases. The thresholds of $1.5 \mathrm{~mm}$ and no-rain periods of $2 \mathrm{~h}$ or less were to ensure enough rainwater to guarantee a fully wet canopy at the time rainfall ceased (Lloyd et al., 1988; Jetten et al, 1996; Dykes, 1997; Schellekens et al., 2000; Manfroi et al., 2004).

\section{RESULTS}

Typical diurnal variations in sap flow velocities measured in sample trees in each canopy level are shown in Figure 3 with diurnal variations in rainfall. The commencement of sap flow velocities in canopy levels 2,3 , and $4(0-20 \mathrm{~m}$ from the ground) after rainfall lagged behind those in canopy level $1(30-50 \mathrm{~m}$ from the ground). When afternoon rainfall occurred, the time lag of the commencement of sap flow velocities after rainfall between canopy level 1 and 2, 3, and 4 spanned 1-2 h 
(Figure 3b). When preceding midnight rainfall occurred, the time lag of the commencement of sap flow velocities between canopy level 1 and 2, 3, and 4 spanned $2-3 \mathrm{~h}$ in the morning (Figure $3 \mathrm{c}$ ). When preceding midnight rainfall was not observed, the time lags between canopy levels in the morning were less distinctive than when preceding midnight rainfall occurred (Figure 3a). This indicated that the time lags of the commencement of sap flow velocities after rainfall between upper and lower canopy trees are caused by the differences in micrometeorological conditions, such as solar radiation, humidity, and wind speed, and differences in canopy drying time after rainfall between the upper and lower canopies.

Figure 4 shows the vertical profiles of canopy drying time after rainfall by sap flow measurements (CDTobs) for four rain events satisfying the three criteria; CDTobs in canopy level 1 were shorter than those in canopy levels 2, 3, and 4. In the case of afternoon rainfall on 24 and 31 August, CDTobs in canopy level 1 distributed around $2 \mathrm{~h}$, while CDTobs in canopy levels 2, 3, and 4 distributed in a range between 2 and $4 \mathrm{~h}$. In the case of midnight rainfall on 11 and 25 September, CDTobs in canopy level 1 distributed around $4 \mathrm{~h}$, while, CDTobs in canopy levels 2, 3, and 4 distributed in a range between 6 and $8 \mathrm{~h}$. In both types of rain event, the lengths of CDTobs in canopy levels 2, 3, and 4 were approximately twice as long as those in canopy level 1, while the differences in CDTobs between canopy level 2, 3, and 4 were not distinctive.

\section{DISCUSSION AND CONCLUSIONS}

Vertical variations in CDTobs were estimated at this site using sap flow velocities (Figure 4). The length of CDTobs in individual trees appears to be strongly related to meteorological conditions above and within the canopy, as well as to water storage holding on leaves in individual trees. Takanashi et al. (2003) reported that a coniferous forest stand (i.e. Japanese cypress forest) had stronger gradients of leaf drying time measured with wetness sensors between the upper and lower canopy than those of this study, despite the continuous canopy height of only $16 \mathrm{~m}$ with an LAI of $4.9 \mathrm{~m}^{2} \mathrm{~m}^{-2}$. In this coniferous forest, the gradients of leaf drying time between the upper and lower canopy spanned approximately $5 \mathrm{~h}$. The gradients of leaf drying time between the upper and lower canopy in the present study were less than $5 \mathrm{~h}$. This implies that wet leaves from the upper to the lower canopy dry out quickly after rainfall at this site, even though it has a $50 \mathrm{~m}$ height forest canopy.

The specific rainfall characteristics of this region could be the reasons for the less distinctive gradients of CDTobs at this site, because spatial and temporal variations in rainfall are more significant in the tropics than in other climatic regions (Houze et al., 1981; Shuin et al., 1996); that is, cloudy weather after rainfall abruptly becomes sunny (Figure 4). For example, larger values of solar radiation $\left(>800 \mathrm{~W} \mathrm{~m}^{-2}\right)$, and vapour pressure (a)
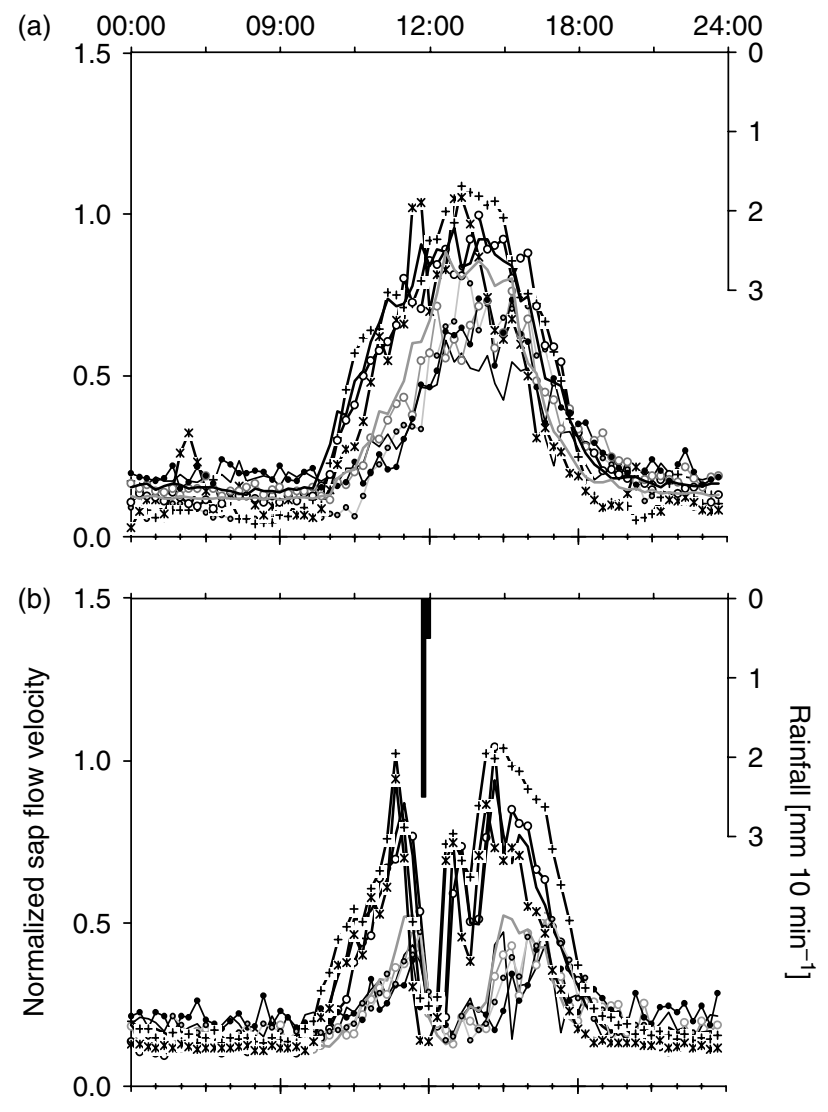

(c) 1.5

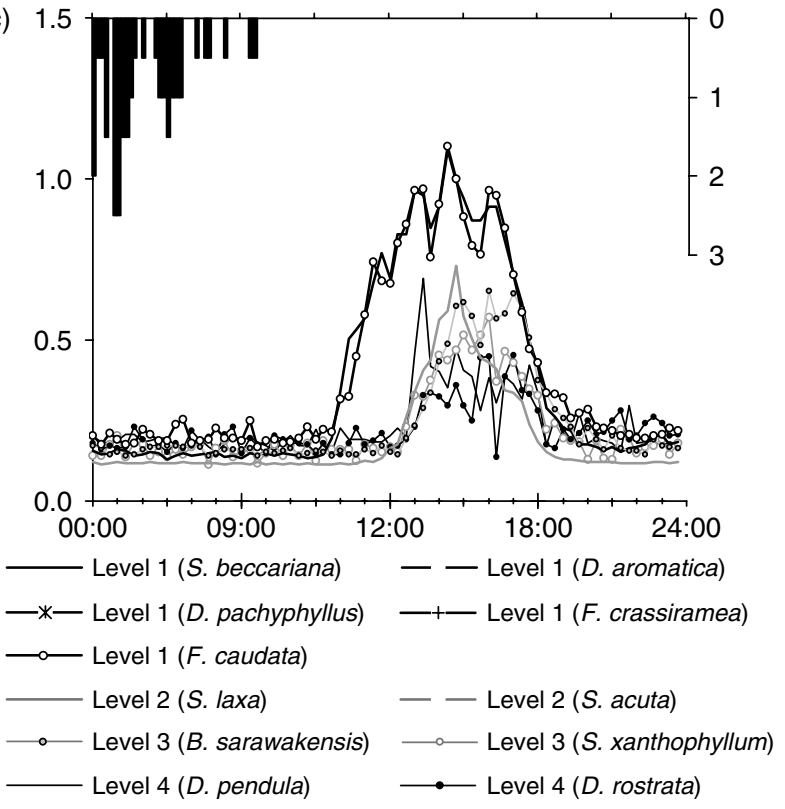

Figure 3. Typical diurnal variations in normalized sap flow velocities measured in individual trees in canopy levels 1, 2, 3, and 4 (Figure 1) with diurnal distributions of rainfall on (a) 28 August, (b) 24 August, and (c) 25 September. Sap flow velocities in individual trees were normalized by the maximum value in the measurement period for each tree

deficit ( $>5 \mathrm{hPa}$ ) were reached less than $2 \mathrm{~h}$ after daytime rainfall at this site (Figure 4), whereas solar radiation and vapour pressure deficit after morning rainfall in the coniferous forest stand remained lower than $400 \mathrm{~W} \mathrm{~m}^{-2}$ and $5 \mathrm{hPa}$, respectively, during daytime. The significantly larger evaporative energy after rainfall at this site than 


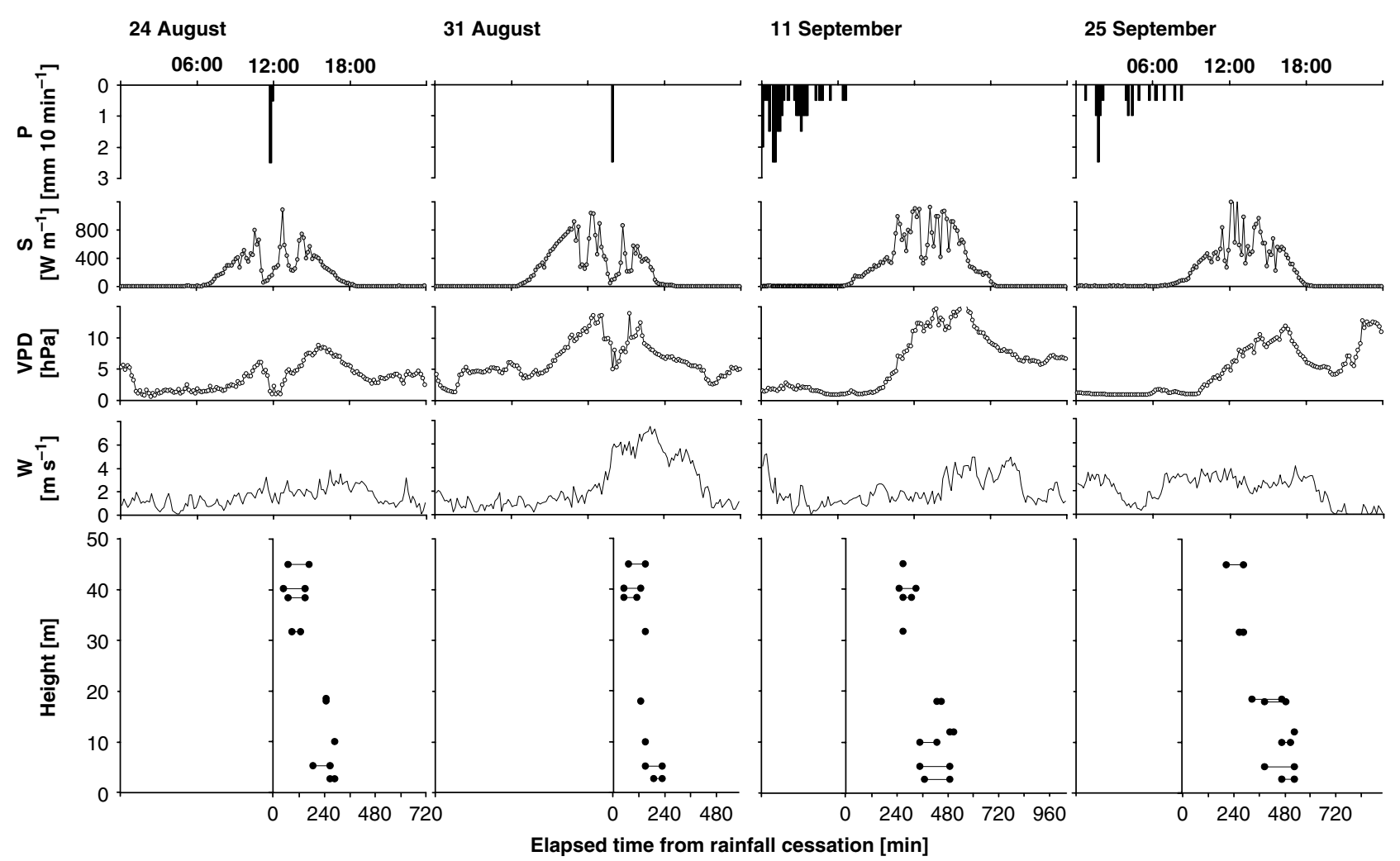

Figure 4. Vertical profiles of CDTobs on 24, 31 August, and 11, 25 September in 2004. Diurnal variations in rainfall $(P)$, solar radiation $(S)$, vapour pressure deficit $(V P D)$, wind speed $(W)$ measured above the canopy are also shown. Horizontal bars with circles at each end represent CDTobs in individual trees

at the coniferous forest stand may cause rapid drying of wet leaves within the forest canopy. Smaller canopy water storage capacity on leaves in tropical rainforests could be another reason for the less distinctive gradients of CDTobs. In a previous study, smaller canopy water storage capacity, ca. $0.7 \mathrm{~mm}$, was reported at this site (Manfroi et al., 2006; Kume et al., 2007b) than that of Takanashi et al. (2003), which was ca. $1.0 \mathrm{~mm}$ (i.e. $0.2 \mathrm{~mm} \mathrm{LAI}^{-1}$ ) at the stand scale. Further, many previous studies have reported small canopy water storage capacity $(<1.0 \mathrm{~mm})$ in tropical forest at the forest canopy scale (Lloyd et al., 1988; Jetten et al, 1996; Dykes, 1997; Schellekens et al., 2000).

This study reports the vertical variations in CDTobs in a Bornean tropical rainforest. Such vertical profiles have not previously been reported in tropical rainforests because of the large and complex canopy, and the lack of facilities for measuring canopy drying time within a forest canopy. The CDTobs profiles presented in this study are a useful illustration of a technique for studying wetcanopy evaporation in tropical rainforests, however, three major practical limitations should be considered. First, a possible time lag between canopy transpiration and stem sap flow may affect the availability of CDTobs. At this site time lags between canopy transpiration and stem sap flow are negligible, but the time lag should be considered at other sites before application of the method presented in this study using a time series analysis (Phillips et al., 1999). Second, the utility of the proposed method is considerably limited by rainfall characteristics. Detecting canopy wetness using sap flow measurements can work well in humid tropics where short rain events tend to occur in the morning and around midday. It would be difficult to apply this method in interior sites within the humid tropics where late afternoon or midnight rain events dominate in the diurnal cycle (Lloyd, 1990; Oki and Musiake, 1994; Chappell et al., 2001; Sorooshian et al., 2002). This limitation may be overcome by using a sap flow velocity modelled on the basis of solar radiation and vapour pressure deficit (Komatsu et al., 2006), instead of the sap flow velocity averaged over bright days. Third, physiological differences among tree species may influence the estimation of CDTobs. In fact, previous studies conducted in lowland dipterocarp rainforest showed variations among species in the diurnal courses of gas exchange due to specific stomatal responses to atmospheric conditions (Eschenbach et al., 1998; Kenzo et al., 2004). Further, stomatal control of transpiration in response to atmospheric conditions can differ under wet and dry soil conditions at this site (Kumagai et al., 2004). Thus, to eliminate the effects of interspecific and temporal variations in physiological responses on estimation of CDTobs, the average diurnal variations in sap flow velocities on bright days should be calculated for each sample tree under wet soil conditions, as performed in this study.

Multi-layer models have not been applied previously to wet-canopy evaporation processes in tropical rainforests with complex canopy structures, thus, the applicability of multi-layer models for wet-canopy evaporation in a tropical rainforest is still unknown. Using the method for 
profiles of CDTobs presented in this study in addition to conventional measurements (Watanabe and Mizutani, 1996; Manfroi et al., 2006) can provide better validation of multi-layer models than when the conventional measurements alone are used. This is because CDTobs enables one to examine whether multi-layer models can reproduce wet-canopy evaporation processes within a forest canopy. Furthermore, sensitivity analysis using the validated multi-layer models will provide a better understanding of how forest canopy structure impacts on meteorological conditions and leaf drying time within a forest canopy.

\section{ACKNOWLEDGMENTS}

This work was supported by the CREST programme of the JST (Japan Science and Technology Agency). We would like to express our appreciation to Ms Lucy Chong of the Forest Research Centre, Sarawak Forest Corporation, and Dr Tohru Nakashizuka of Tohoku University for their cooperation with our work in Lambir. Some of the equipment was installed by $\mathrm{Mr}$ Hidenori Arata and $\mathrm{Mr}$ Toshinobu Horiuchi, both from the University of Tokyo. Fruitful discussions with Dr Nobuaki Tanaka and Assistant Professor Norifumi Hotta, both from the University of Tokyo, are also greatly appreciated.

\section{REFERENCES}

Asdak C, Jarvis PG, van Gardingen P, Frase A. 1998. Rainfall interception loss in unlogged forest area of Central Kalimantan, Indonesia. Journal of Hydrology 206: 237-244. DOI: 10·1016/S00221694(98)00108-5.

Baldocchi DD, Wilson KB. 2001. Modeling $\mathrm{CO}_{2}$ and water vapor exchange of a temperate broadleaved forest across hourly to decadal time scales. Ecological Modeling 142: 155-184.

Bosveld FC, Bouten W. 2003. Evaluation a model of evaporation and transpiration with observations in a partially wet douglas-fir forest. Boundary Layer Meteorology 108: 365-396.

Chappell NA, Bidin K, Tych W. 2001. Modeling rainfall and canopy controls on net-precipitation beneath selectively-logged tropical forest. Plant Ecology 153: 215-229.

Closs RH. 1958. The heat pulse method for measuring rate of sap flow in a plant stem. New Zealand Journal of Science 1: 281-288.

Condit R, Ashton PS, Baker P, Bunyavejchewin S, Gunatilleke S, Gunatilleke N, Hubbell SP, Foster RB, Itoh A, LaFrankie JV, et al. 2000. Spatial patterns in the distribution of tropical tree species. Science 288: $1414-1418$.

Dykes AP. 1997. Rainfall interception from a lowland tropical rainforest in Brunei. Journal of Hydrology 200: 260-279. DOI: 10·1016/s00221694(97)00023-1.

Eschenbach C, Glauner R, Kleine M, Kappen L. 1998. Photosynthesis rates of selected tree species in lowland dipterocarp rainforest of Sabah, Malaysia. Trees-Structure and Function 12: 356-365.

Goldstein G, Andrade JL, Meinzer FC, Holbrook NM, Cavelier J, Jackson P, Celis A. 1998. Stem water storage and diurnal patterns of water use in tropical forest canopy trees. Plant, Cell and Environment 21: $397-406$.

Gomyo M, Kuraji K. 2006. Spatial distribution of seasonal variation in rainfall in the state of Sarawak, Malaysia. Journal of Japan Society Hydrology \& Water Resources 19: 128-138 (in Japanese with English summary).

Houghton RA, Hackler JL. 1999. Emission of carbon from forestry and land-use change in tropical Asia. Global Change Biology 5: 481-492. DOI: $10 \cdot 1046 / \mathrm{j} .1365-2486 \cdot 1999 \cdot 00244 . x$.

Houze RA, Geotis SG, Marks FD, West AK. 1981. Winter monsoon convection in the vicinity of north Borneo. Part 1: Structure and time variation of the clouds and precipitation. Monthly Weather Review 109: $1595-1614$.

Itoh A, Yamakura T, Ogino K, Lee HS, Ashton PS. 1997. Spatial distribution patterns of two predominant emergent trees in a tropical rainforest in Sarawak, Malaysia. Plant Ecology 132: 121-136.

Jackson IJ. 1975. Relationships between rainfall parameters and interception by tropical forest. Journal of Hydrology 24: 215-238.

Jetten VG. 1996. Interception of tropical rain forest: performance of a canopy water balance model. Hydrological Processes 10: 671-685.

Kajitani N, Hotta N, Komatsu H, Kume T, Suzuki M. 2005. Differences in diurnal patterns of transpiration between young Sugi trees (Cryptomeria Japonica) located at the ridge and the bottom of a slope Journal of the Japan Forestry Society 87: 63-72 (in Japanese with English summary).

Kanae S, Oki T, Musiake K. 2001. Impact of deforestation on regional precipitation over the Indochina Peninsula. Journal of Hydrometeorology 2: 51-70.

Kenzo T, Ichie T, Yoneda R, Kitahashi Y, Watanabe Y, Ninomiya I, Koike T. 2004. Interspecific variation of photosynthesis and leaf characteristics in canopy trees of five species of Dipterocarpaceae in a tropical rain forest. Tree Physiology 24: 1187-1192.

Kira T. 1978. Community architecture and organic matter dynamics in tropical lowland rain forests of southeast Asia with special reference to Pasoh Forest, West Malaysia. In Tropical Trees as Living Systems, Tomlinson TB, Zinmerman MH (eds). Cambridge University Press: Cambridge; 561-590.

Kominami Y, Suzuki M. 1993. Comparison of transpiration rate measured by heat pulse method and water uptake rate in single trees of Chamaecyparis obtusa and Pinus densiflora. In Exchange Processes at the Land Surface for a Range of Space and Time Scales, Bolle H-J, Feddes RA, Kalma JD (eds.). IAHS Publication No. 212. IAHS Press: Wallingford; 27-34.

Komatsu H, Kang Y, Kume T, Yoshifuji N, Hotta N. 2006. Transpiration from a Cryptomeria japonica plantation: II Responses of canopy conductance to meteorological factors. Hydrological Processes 20: $1321-1334$.

Kumagai T. 2001. Modeling water transportation and storage in sapwood-model development and validation. Agricultural and Forest Meteorology 109: 105-115.

Kumagai T, Kuraji K, Noguchi H, Tanaka Y, Tanaka K, Suzuki M. 2001. Vertical profiles of environmental factors within tropical rainforest, Lambir Hills National Park, Sarawak, Malaysia. Journal of Forest Research 6: 257-264.

Kumagai T, Saitoh TM, Sato Y, Morooka T, Manfroi OJ, Kuraji K, Suzuki M. 2004. Transpiration, canopy conductance and the decoupling coefficient of a lowland mixed dipterocarp forest in Sarawak, Borneo: dry spell effects. Journal of Hydrology 287: $237-251$

Kumagai T, Saitoh TM, Sato Y, Takahashi H, Manfroi OJ, Morooka T., Kuraji K, Suzuki M, Yasunari T, Komatsu H. 2005. Annual water balance and seasonality of evapotranspiration in a Bornean tropical rainforest. Agricultural and Forest Meteorology 128: 81-92.

Kumagai T, Ichie T, Yoshimura M, Yamashita M, Kenzo T, Saitoh TM, Ohashi M, Suzuki M, Koike T, Komatsu H. 2006. Modeling CO2 exchange over a Bornean tropical rain forest using measured vertical and horizontal variations in leaf-level physiological parameters and leaf area densities. Journal of Geophysical Research-Atmosphere 111: D10107, DOI:10·1029/2005JD006676.

Kume T, Kuraji K, Yoshifuji N, Morooka T, Sawano S, Chong L, Suzuki M. 2006. Estimation of canopy drying time after rainfall using sap flow measurements in an emergent tree in a lowland mixeddipterocarp forest in Sarawak, Malaysia. Hydrological Processes 20: 565-578.

Kume T, Komatsu H, Kuraji K, Suzuki M. 2007a. Less than 20-minute time lags between transpiration and stem sap flow in emergent trees in a Bornean tropical rainforest. Submitted to Agricultural and Forest Meteorology (in press).

Kume T, Manfroi OJ, Kuraji K, Tanaka N, Horiuchi T, Suzuki M, Kumagai T. 2007b. Estimation of canopy water storage capacity from sap flow measurements in a Bornean tropical rainforest. Submitted to Journal of Hydrology (in press).

Kuraji K, Tanaka N. 2003. Rainfall interception studies in the tropical forests. Journal of the Japan Forestry Society 85: 18-28 (in Japanese with English summary).

Landsberg JJ, Blanchard TW, Warrit B. 1976. Studies on the movement of water through apple trees. Journal of Experimental Botany 27: $579-596$. 
Lai C-T, Katul G, Ellsworth D, Oren R. 2000. Modelling vegetationatmosphere $\mathrm{CO} 2$ exchange by a coupled Eulerian-Lagrangian approach. Boundary Layer Meteorology 95: 91-122.

Lean J, Warrilow DA. 1989. Simulation of the regional climate impact of Amazon deforestation. Nature 342: 411-413.

Lindroth A. 1993. Aerodynamic and canopy resistance of short-rotation forest in relation to leaf area index and climate. Boundary Layer Meteorology 66: 265-279.

Lloyd CR, Gash JHC, Shuttleworth WJ. 1988. The measurement and modeling of rainfall interception by Amazonian rain forest. Agricultural and Forest Meteorology 43: 277-294. DOI: 10·1016/01681923(88)90055-X.

Lloyd CR. 1990. The temporal distribution of Amazonian rainfall and its implications for forest interception. Quarterly Journal of the Royal Meteorological Society 116: 1487-1494.

Mabuchi K, Sato Y, Kida H. 2005. Climatic impact of vegetation change in the Asian tropical region. Part I: Case of the northern hemisphere summer. Journal of Climate 18: 410-428.

Malhi Y, Grace J. 2000. Tropical forests and atmospheric carbon dioxide. Trends in Ecology \& Evolution 15: 332-337.

Manfroi OJ, Kuraji K, Tanaka N, Suzuki M, Nakagawa M, Nakashizuka T, Chong L. 2004. The stemflow of trees in a Bornean lowland tropical forest. Hydrological Processes 18: 2455-2474. DOI: 10.1002/hyp. 1474.

Manfroi OJ, Kuraji K, Suzuki M, Tanaka N, Kume T, Nakagawa M, Kumagai T, Nakashizuka T. 2006. Comparison of conventionally observed interception evaporation in a $100-\mathrm{m}^{2}$ subplot with that estimated in a 4-ha area of the same Bornean lowland tropical forest. Journal of Hydrology 329(1-2): 329-349.

Marshall DC. 1958. Measurement of sap flow in conifers by heat transport. Plant Physiology 33: 385-396.

Nakagawa M, Tanaka K, Nakashizuka T, Ohkubo T, Kato T, Maeda T, Sato K, Miguchi H, Nagamasu H, Ogino K, Teo S, Hamid AA Seng LH. 2000. Impact of severe drought associated with the 1997-1998 El Niño in a tropical forest in Sarawak. Journal of Tropical Ecology 16: 355-367.

Nakashizuka T, Lee HS, Chong L. 2001. Studies on canopy processes of a tropical rain forest in Lambir Hills National Park. In Proceedings of the International Symposium. Canopy Processes and Ecological Roles of Tropical Rain Forest, T Ichioka, et al. (eds). Sarawak, Malaysia, Miri; 2-7.

Noguchi S, Abdul Rahim N, Tani M. 2003. Rainfall characteristics of tropical rainforest at Pasoh Forest Reserve, Negeri Sembilan, Peninsuar Malaysia. In Paso Ecology of a Lowland Rain Forest in Southeast Asia, Okuda T, Manokaran N, Matsumoto Y, Niiyama K, Thomas SC, Ashton PS (eds). Springer-Verlag: Tokyo; 51-58.

Oki T, Musiake K. 1994. Seasonal change of the diurnal cycle of precipitation over Japan and Malaysia. Journal of Applied Meteorology 33: $1445-1463$.

Ozanne CMP, Anhuf D, Boulter SL, Keller M, Kitching RL, Körner C, Meinzer FC, Mitchell AW, Nakashizuka T, Silva Dias PL, Stork NE, Weight SJ, Yoshimura M. 2003. Biodiversity meets the atmosphere: a global view of forest canopies. Science 3001: 183-186.

Park H, Hattori S. 2004. Modeling scalar and heat sources, sinks, and fluxes within a forest canopy during and after rainfall. Journal of Geophysical Research-Atmosphere 109: D14301, DOI:10·1029/2003JD004360.
Phillips N, Nagchaudhuri A, Oren R, Katul G. 1997. Time constant for water transport in loblolly pine trees estimated from time series of evaporative demand and stem sapflow. Trees 11: 412-419.

Phillips N, Oren R, Zimmermann R, Wright SJ. 1999. Temporal patterns of water flux in trees and lianas in a Panamanian moist forest. Trees 14: $116-123$.

Rutter AJ, Morton AJ, Robins PC. 1975. A predictive model of rainfall interception in forests (II) Generalization of the model and comparison with observations in some coniferous and hardwood stands. Journal of Applied Ecology 12: 367-380.

Scatena FN. 1990. Watershed scale rainfall interception on two forested watersheds in the Luquillo Mountains of Puerto Rico. Journal of Hydrology 113: 89-102.

Schellekens J, Bruijnzeel LA, Scatena FN, Bink NJ, Holwerda F. 2000. Evapotranspiration from a tropical rain forest, Luquillo Experimental Forest, eastern Puerto Rico. Water Resources Research 36: 2183-2196. Sorooshian S, Gao X, Hsu K, Maddox RA, Hong Y, Gupta HV, Imam B. 2002. Diurnal variability of tropical rainfall retrieved from combined GOES and TRMM satellite information. Journal of Climate 15: $983-1001$.

Swanson RH, Whitfield DWA. 1981. A numerical analysis of heat pulse velocity theory and practice. Journal of Experimental Botany 32: $221-239$.

Shuin Y, Shibano M, Suzuki M, Ohta T. 1996. Temporal and spatial characteristics of rainfall at a south-west slope of volcanic Mt. Merapi in Indonesia. Journal of Japan Society Erosion Control Engineering 48: $3-12$

Takanashi S, Kosugi Y, Tani M, Ohte N, Yano M, Tanaka H, Tanaka K. 2003. Evaporation from a Japanese cypress forest during and after rainfall. Journal of Japan Society Hydrology \& Water Resources 16: 268-283 (in Japanese with English summary).

Tanaka K. 2002. Multi-layer model of $\mathrm{CO}_{2}$ exchange in a plant community coupled with the water budget of leaf surfaces. Ecological Modeling 147: 85-104.

Tanaka K, Takizawa H, Tanaka N, Kosaka I, Yosifuji N, Tantasirin C, Piman S, Suzuki M, Tangtham N. 2003. Transpiration peak over a hill evergreen forest in northern Thailand in the late dry season: Assessing the seasonal change in evapotranspiration using a multi-layer model. Journal of Geophysical Research-Atmosphere 108: 4533-4548. DOI: 10.1029/2002JD003028.

Watanabe T, Mizutani K. 1996. Model study on micrometeorological aspects of rainfall interception over an evergreen broad-leaved forest. Agricultural and Forest Meteorology 80: 195-214. DOI: 10.1016/0168-1923(95)02301-1.

Whitmore TC. 1994. An Introduction to Tropical Rain Forests. Oxford University Press: Oxford; 9-35.

Williams M, Malhi Y, Nobre AD, Rastetter EB, Grace J, Pereira MGP. 1998. Seasonal variation in net carbon exchange and evapotranspiration in a Brazilian rain forest: A modeling analysis. Plant, Cell and Environment 21: 953-968.

Yamakura T, Kanzaki M, Itoh A, Ohkubo T, Ogino K, Chai EOK, Lee HS, Ashton PS. 1995. Forest architecture of Lambir rain forest revealed by a large-scale research plot. In Reports of new program for promotion of basic sciences: Studies of global environ. changes with special reference to Asia and Pacific regions, Ehime University, Japan, Vol. II-3. 2-20. 